\title{
Comparative Study of Analysis of Elevated Water Tank Due To Earth Quake from Different Zones of Earth Quake
}

\author{
P.L.N. Saroja \\ Student of Final Year M.Tech Structural Engineering \\ Usha Rama College of Engineering and Technology, Andhra Pradesh \\ Vanka. Srinivasa Rao, B.E, M.Tech (NIT-W), (Ph.D.) \\ Associate Professor, Civil Engineering Department \\ Usha Rama College of Engineering and Technology, Andhra Pradesh
}

\begin{abstract}
The main aim of this study is to analyse the elevated water tank and comparing the forces created on elevated water tank in different seismic zones due to earthquake. Any civil engineering structures are conceived keeping in mind its intended use, the materials available, cost and aseptic, considerations.The analysis of elevated water tank is performed on impulsive mode and convective mode using the code IS 1893 (part 2) 2002 and also we considered the forces in both tank full condition and tank empty condition. From this study the forces acting on elevated water tank due to seismic forces are calculated for all the zones and also the Base shear, Base moment values are compared from zone I to zone IV. The Horizontal forces due to seismic and wind effect are also calculated. Then finally the values are represented in the form of tables and graphs.
\end{abstract}

Keywords: Elevated water tank, Analysis, Comparison of forces

\section{INTRODUCTION}

Water is human basic needs for daily life. Elevated water tanks consists of a huge water mass at a the top of slender staging which are most critical consideration for the failure of the tank during earthquakes, elevated water tanks are critical and strategic structures and damage of these structures during earthquakes may endanger drinking water supply, cause to fail in preventing large fires and substantial economical loss. The performance of elevated water tanks during earthquakes is of much interest to engineers, not only because of the important of these tanks in controlling fires, but also because the simple structure of an elevated tank is relatively easy to analyse and, hence the study of tanks can de informative as to the behaviour of structures during earthquakes.

\section{DEFinition OF WATER TANK}

A water tank is a container for storing water. The need for a water tank is as old as civilisation, providing storage of water for drinking water, irrigation agriculture, fire suppression, agricultural farming, both for plants and livestock, chemical manufacturing, food preparation as well as many other applications.

\section{Elevated Water TANK}

Water is day by day essential requirement for each human life. A raised Reinforced Concrete roundabout tank is a water storage tank built with the end goal of holding water supply at certain tallness to pressurize the water circulation framework. Numerous new thoughts and developments have been made for the capacity of water and other fluid materials in distinctive structures and molds. There are distinctive routes for the capacity of fluid, for example, underground tanks, ground bolstered tanks, lifted tanks and so on. Indian sub-continent is exceptionally defenceless against characteristic debacles like quakes, drafts, surges, violent winds and so on. Greater parts of states or union domains are inclined to one or numerous calamities. These regular catastrophes are bringing on numerous setbacks and countless property misfortune consistently. Seismic tremors involve ahead of everyone else in powerlessness. As per seismic code IS: 1893(Part I):2002, more than 60\% of India is inclined to tremors. After a seismic tremor, property misfortune can be recuperated to some degree nonetheless, the life misfortune can't. 


\section{SEISMIC ZONES IN INDIA}

The problem of designing economical earthquake-resistant structures rests heavily on the determination of reliable quantitative estimates of expected earthquake intensities in particular region. However, it is not possible to predict with any certainty when and where earthquake will occur, how strong they will be, and what characteristics the ground motions will have. Therefore, an Engineer must estimate the ground shaking. A simple method is to use a seismic zone map, where in the area is sub divided into regions, each associated with a known or assigned seismic probability or risk. To serve as a useful basis for the implementation of code provisions on earthquake resistant design. The present earthquake zoning map used in India shows the country divided into four zones of approximately equal seismic probability, depending upon the local hazards.

\begin{tabular}{|c|c|c|c|}
\hline Seismic zone2 & Seismic zone 3 & Seismic zone 4 & Seismic zone 5 \\
\hline $\begin{array}{c}\text { Moderately susceptible to } \\
\text { earthquake }\end{array}$ & $\begin{array}{c}\text { Most susceptible to } \\
\text { earthquake }\end{array}$ & $\begin{array}{c}\text { Affected towards } \\
\text { zone }\end{array}$ & $\begin{array}{c}\text { Highly affected to } \\
\text { earthquake }\end{array}$ \\
\hline
\end{tabular}

\section{Indian Code Provisions}

Two mass models for elevated tank were proposed by Housner [Housner, 1963] which is more appropriate and is being commonly used in most of the international codes. The pressure generated within the fluid due to the dynamic motion of the tank can be separated into impulsive and convective parts.

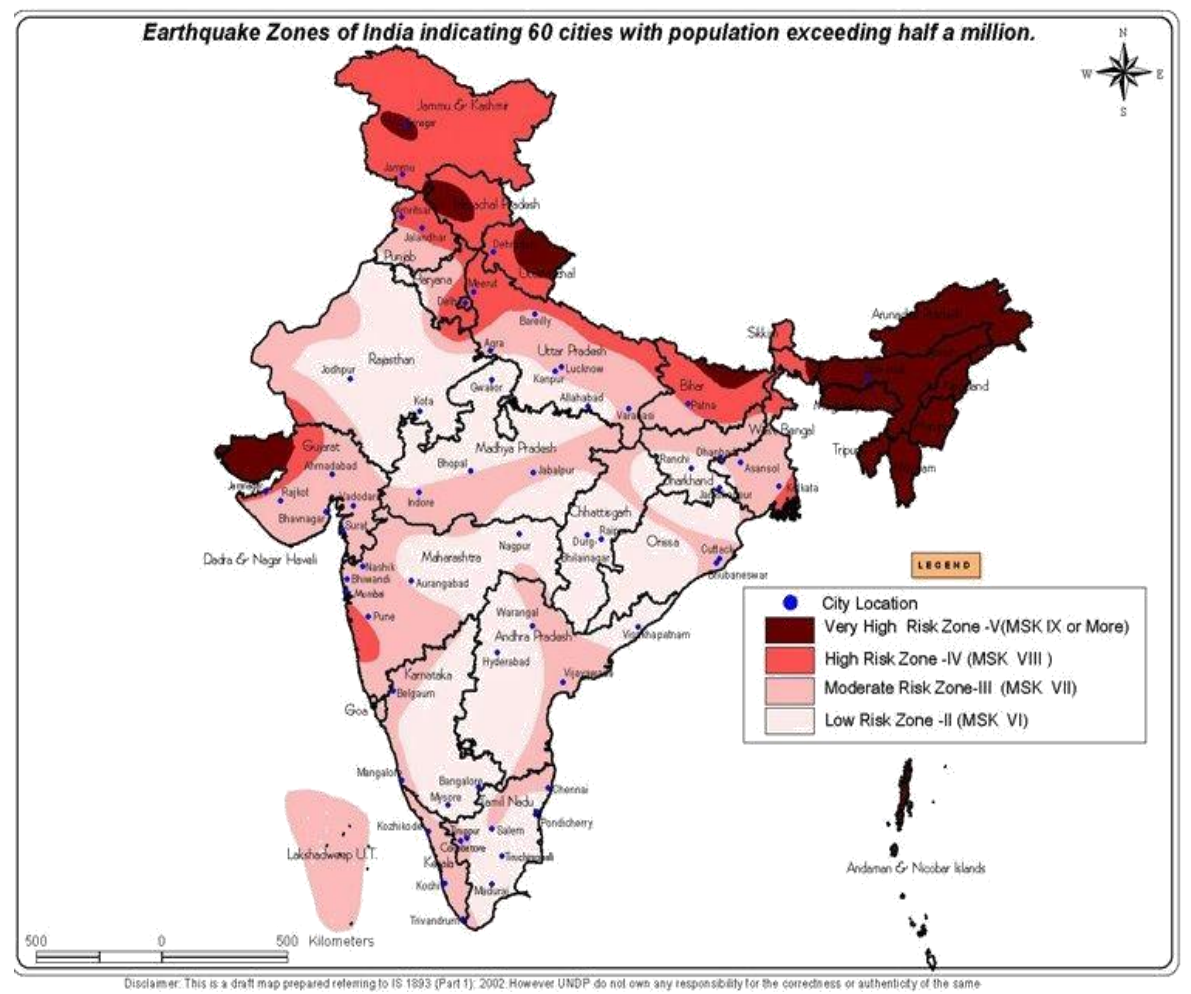

Fig1. Different Earthquake Zones of India

Impulsive liquid mass: When a tank containing liquid with a free surface is subjected to horizontal earthquake ground motion, tank wall and liquid are subjected to horizontal acceleration. The liquid in the lower region of tank behaves like a mass that is rigidly connected to tank wall. This mass is termed as impulsive liquid mass which accelerates along with the wall and induces impulsive hydrodynamic pressure on tank wall and similarly on base.

Convective liquid mass: Liquid mass in the upper region of tank undergoes sloshing motion. This mass is termed as convective liquid mass and it exerts convective hydrodynamic pressure on tank wall and base.

In the spring mass model of tank, hi is the height at which the resultant of impulsive hydrodynamic pressure on wall is located from the bottom of tank wall. On the other hand, hi* is the height at which the resultant of impulsive pressure on wall and base is located from the bottom of tank wall. Thus, if 

Earth Quake

effect of base pressure is not considered, impulsive mass of liquid, mi will act at a height of hi and if effect of base pressure is considered, mi will act at hi*.Similarly, hc, is the height at which resultant of convective pressure on wall is located from the bottom of tank wall, while, hc* is the height at which resultant of convective pressure on wall and base is located.

The spring mass model of the ta nk is shown below.

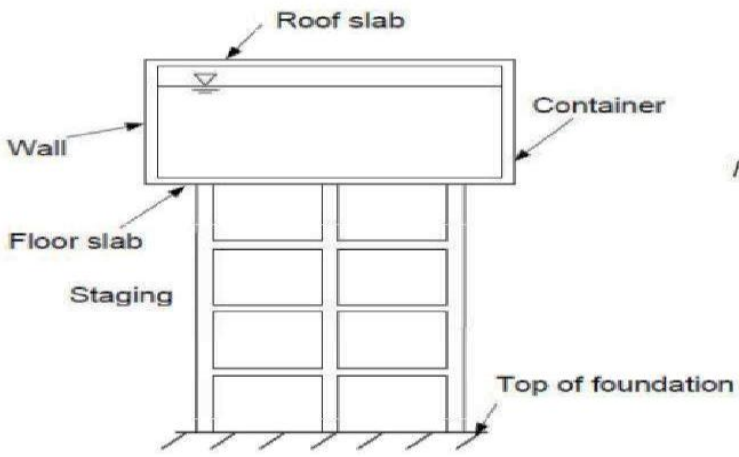

(a) Elevated tank

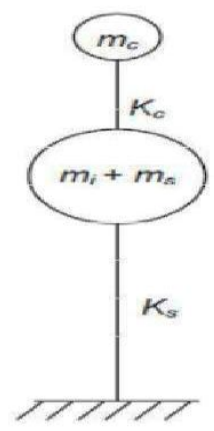

(c) Two mass idealization of elevated tank

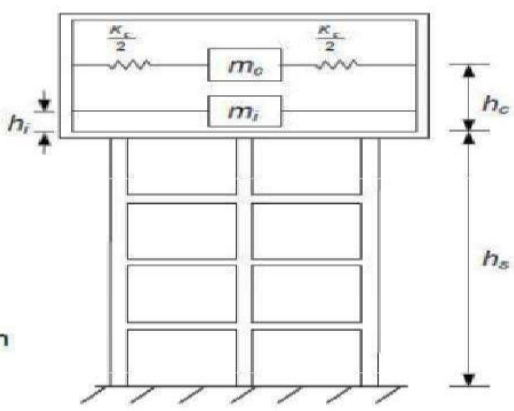

(b) spring mass model

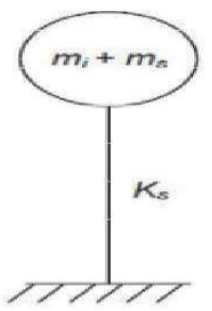

(d) Equivalent uncoupled system

Fig2. Two mass idealization for elevated tank

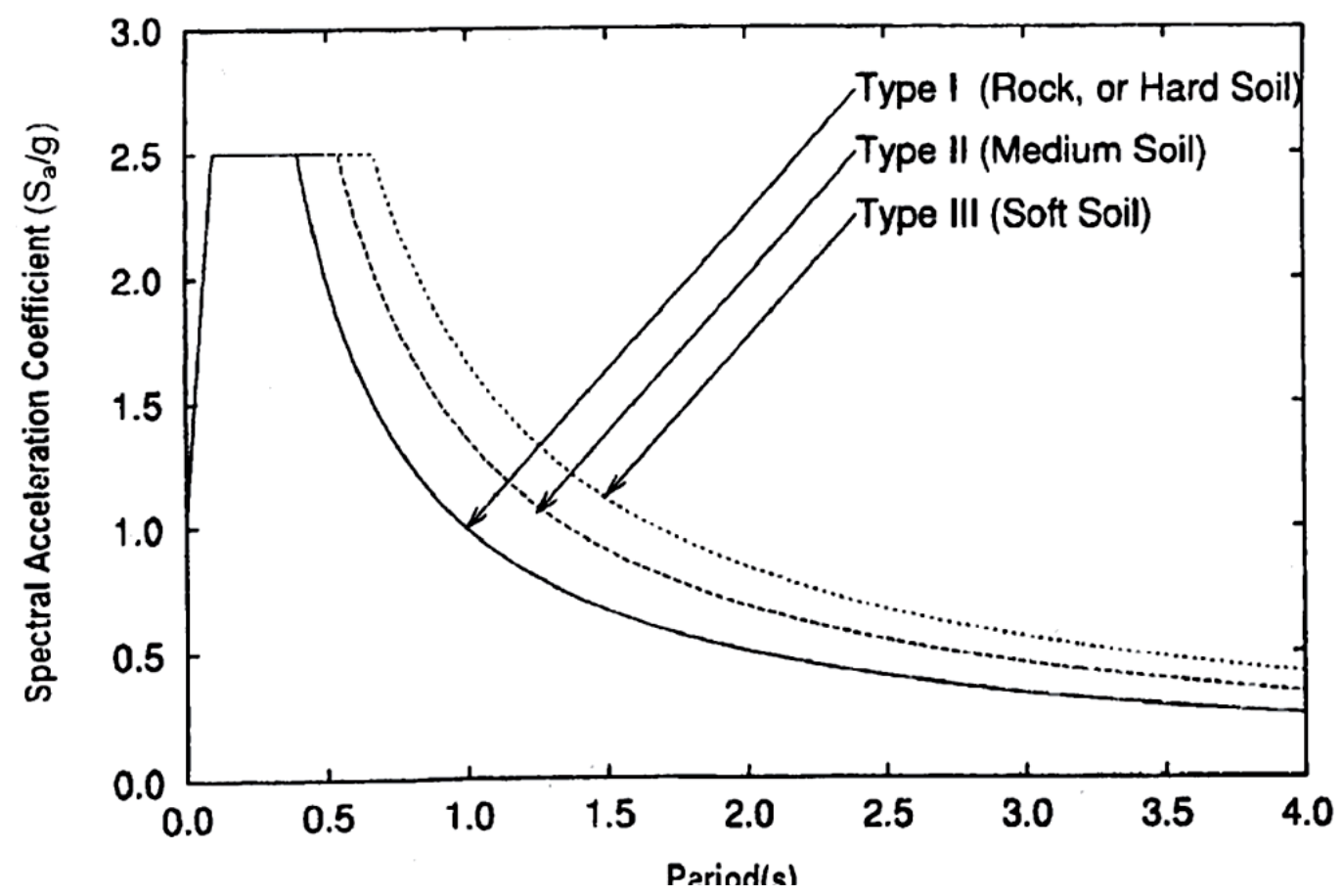

Fig3. Response spectra for $5 \%$ damping 
P.L.N. Saroja \& Vanka. Srinivasa Rao

\section{ANALYSIS OF ELEVATED INTZE TANK SUPORTED ON 6 COLUMN RC STAGING:}

\section{I.Preliminary Data:}

Details of sizes of various components and geometry are shown below table

\begin{tabular}{|c|c|c|}
\hline S. No & Component & Size (mm) \\
\hline 1 & Top Dome & 100 Thick \\
\hline 2 & Top Ring Beam & $150 \times 250$ \\
\hline 3 & Cylindrical Wall & 200 Thick \\
\hline 4 & Bottom Ring Beam & $600 \times 300$ \\
\hline 5 & Circular Ring Beam & $300 \times 600$ \\
\hline 6 & Bottom Dome & 200 Thick \\
\hline 7 & Conical Dome & 200 Thick \\
\hline 8 & Braces & $250 \times 350$ \\
\hline 9 & Columns & 500 diameter \\
\hline
\end{tabular}

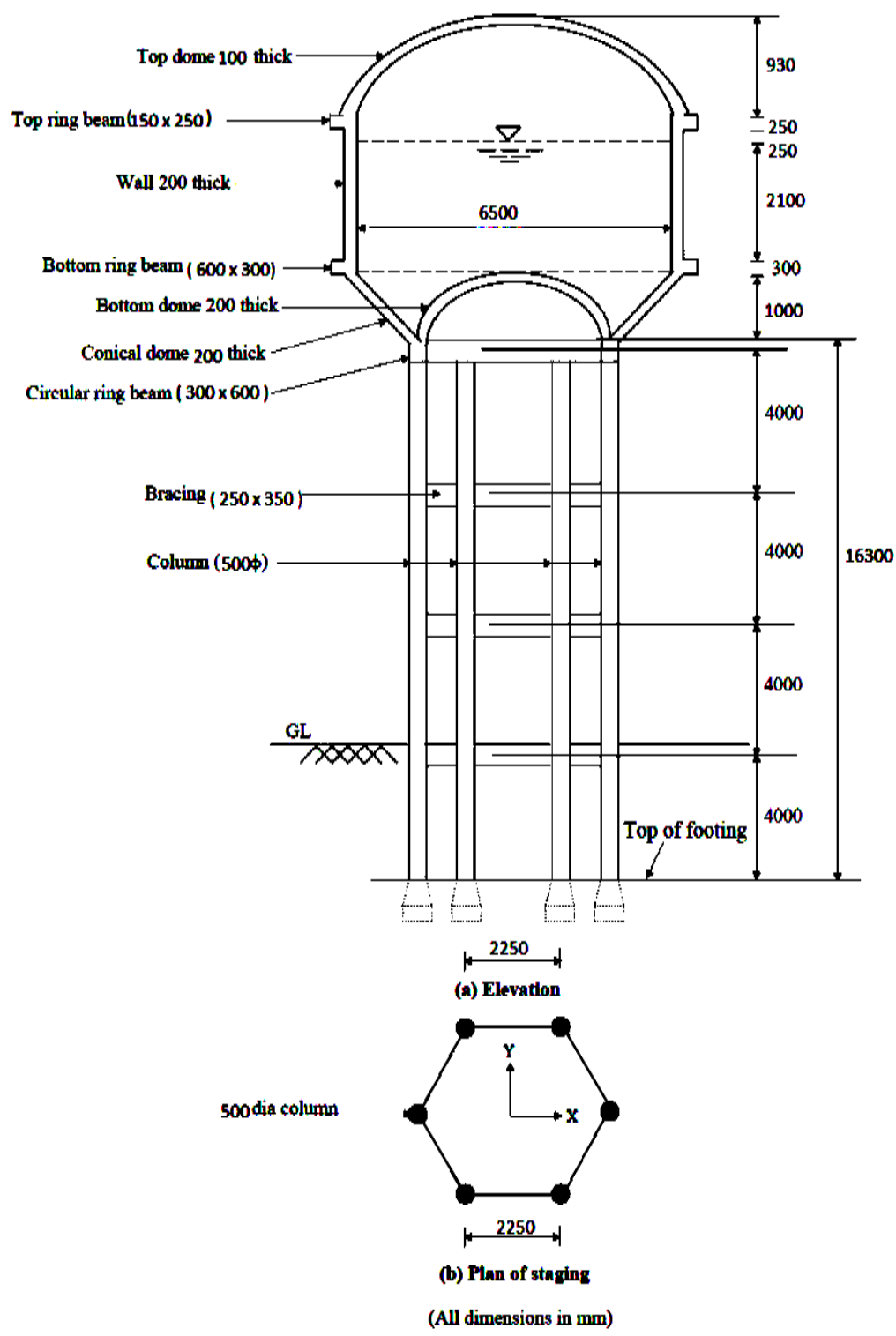

Fig4. Section of elevated intze water tank 
Comparative Study of Analysis of Elevated Water Tank Due To Earth Quake from Different Zones of Earth Quake

\begin{tabular}{|c|c|c|}
\hline Components & Calculations & Weight $(\mathrm{kN})$ \\
\hline Top Dome & $\begin{array}{l}\left.\text { Radius of dome, } r_{1}=\left[\left((6.7 / 2)^{2} / 0.88\right)+0.88\right)\right] / 2=6.82 \\
2 \times \pi \times 6.82 \times 0.88 \times(0.1 \times 25)\end{array}$ & 94.25 \\
\hline Top Ring Beam & $\pi \times(6.5+0.15) \times 0.15 \times 0.15 \times 25$ & 19.58 \\
\hline Cylindrical Wall & $\pi \times 6.7 \times 0.1 \times 2.35 \times 25$ & 123.63 \\
\hline Bottom Ring Beam & $\pi \times(6.5+0.6) \times 0.6 \times 0.30 \times 25$ & 100.35 \\
\hline Circular Ring Beam & $\pi \times 4.5 \times 0.30 \times 0.60 \times 25$ & 63.6 \\
\hline Bottom Dome & $\begin{array}{l}\left.\text { Radius of dome, } r_{2}=\left[(4.5 / 2)^{2} / 0.9\right)+0.9\right] / 2=3.26 \\
2 \times \pi \times 3.26 \times 0.90 \times 0.10 \times 25\end{array}$ & 46.07 \\
\hline Conical Dome & $\begin{array}{l}\text { Length of Cone, } L_{c}=\left(1.15^{2}+1.15^{2}\right)^{1 / 2}=1.63 \\
\pi \times((6.7+4.5) / 2.0) \times 1.63 \times 0.2 \times 25\end{array}$ & 143.38 \\
\hline Water & $\begin{array}{l}{\left[\left(\pi \times 6.5^{2} \times 2.1 / 4\right)+\left(\pi \times 1.0\left(6.5^{2}+4.0^{2}+(6.5 \times 4.0)\right) / 12\right.\right.} \\
\left.\quad-\left(\pi \times 0.8^{2} \times(3 \times 3.26-1.0) / 3\right)\right] \times 9.81\end{array}$ & 842.25 \\
\hline Columns & $\pi \times(0.50)^{2} \times 15.7 \times 6 \times 25 / 4$ & 462.40 \\
\hline Braces & $2.25 \times 0.25 \times 0.35 \times 3 \times 6 \times 25$ & 88.59 \\
\hline
\end{tabular}

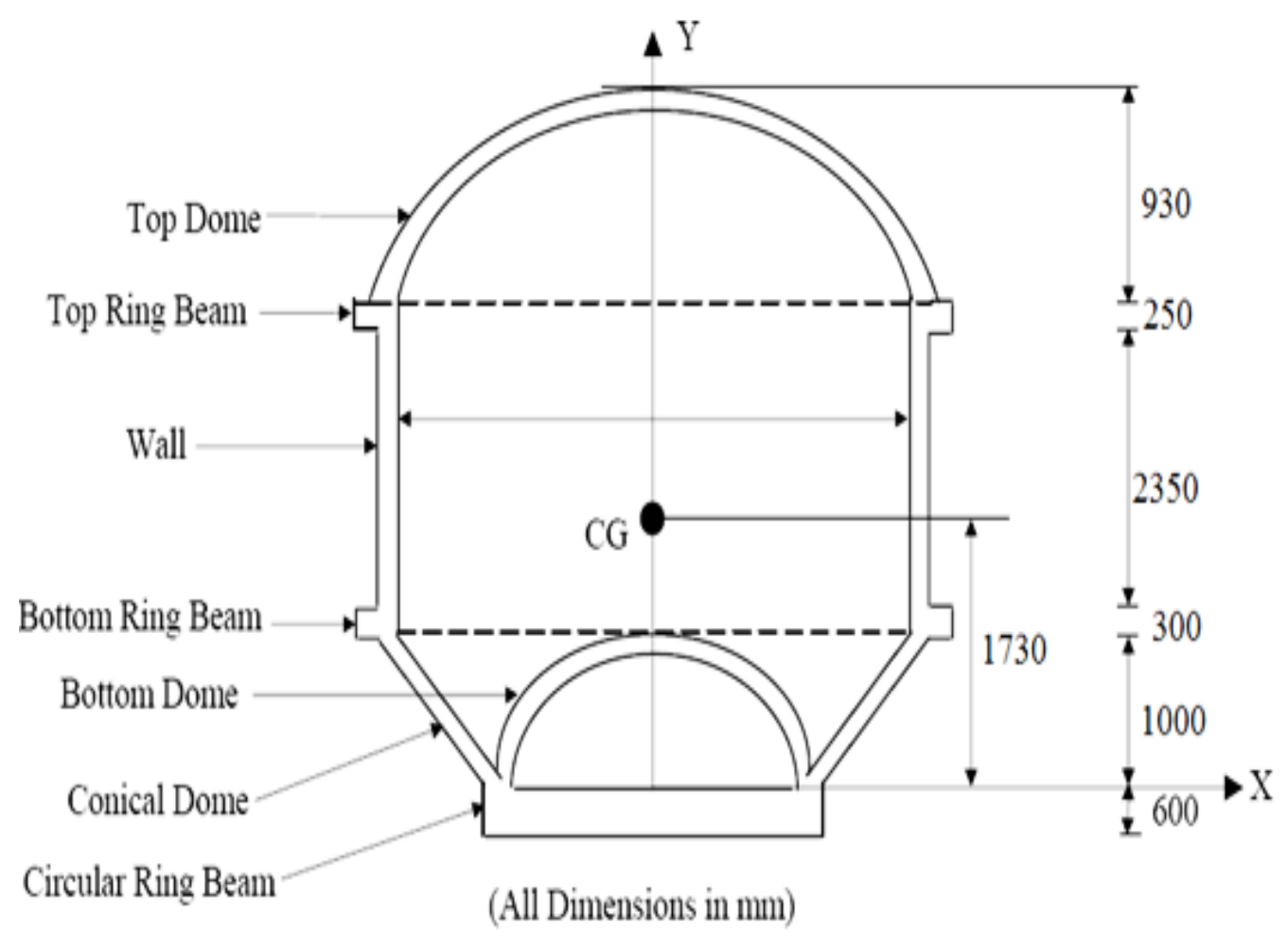

Fig5. Container parameters in frame staging tank 


\section{COMParison}

Consideration of different seismic zones, the forces obtained from the analysis isshown in the below table 1 and comparison of base shear and base moment in tank empty and tank full conditions between different seismic zones is shown in table 2 .

Table1. Comparison of Forces between Different Seismic Zones

\begin{tabular}{|c|c|c|c|c|}
\hline Zone & II & III & IV & V \\
\hline Base shear $(\mathbf{k N})$ & 55.18 & 87.39 & 129.58 & 195.52 \\
\hline Base moment $\mathbf{( k N - m )}$ & 1012.69 & 1604.08 & 2405.47 & 3588.28 \\
\hline Hydrodynamic pressure $\left(\mathbf{k N} / \mathbf{m}^{\mathbf{2}}\right)$ & 3.57 & 5.96 & 8.95 & 12.71 \\
\hline Sloshing wave height(m) & 0.15 & 0.236 & 0.34 & 0.53 \\
\hline
\end{tabular}

Table2. Comparison of Base Shear and Base Moment in Tank Empty and Tank Full Conditions Between Different Seismic Zones

\begin{tabular}{|c|c|c|c|c|}
\hline \multirow{2}{*}{ Zone } & \multicolumn{2}{|c|}{ Base shear $(\mathbf{k N})$} & \multicolumn{2}{c|}{ Base moment(kN-m) } \\
\cline { 2 - 5 } & Tank empty & Tank full & Tank empty & Tank full \\
\hline II & 44.61 & 55.18 & 804.36 & 1012.69 \\
\hline III & 71.25 & 87.39 & 1284.75 & 1604.08 \\
\hline IV & 108.43 & 129.58 & 1955.05 & 2405.47 \\
\hline V & 160.32 & 195.52 & 2890.69 & 3588.28 \\
\hline
\end{tabular}

\section{Distribution of BaSe Shear:}

The Base shear is distributed to the four portions i.e., at cylindrical wall, at conical dome, columns above $10 \mathrm{~m}$ and columns up to $10 \mathrm{~m}$ and values are shown in the below tables $3,4,5,6$.

Table3. Comparison of Distribution of Base Shear in Zone - Ii

\begin{tabular}{|c|c|c|c|c|c|c|}
\hline \multirow{2}{*}{ Element } & \multicolumn{2}{|c|}{ Force per unit height $(\mathbf{k N})$} & \multirow{2}{*}{$\begin{array}{c}\text { Height of } \\
\end{array}$} & Tank full & Tank empty & \multicolumn{2}{|c|}{ Total horizontal force } & Centre of \\
& element & Tank full & Tank empty & gravity \\
\hline Cylindrical portion & 1180.8 & 337.83 & 3.83 & 20.30 & 6.379 & 1.72 \\
\hline Conical dome & 189.452 & 189.452 & 4.83 & 4.135 & 4.46 & 0.66 \\
\hline Shaft above 10m & 132.47 & 132.47 & 7.12 & 4.19 & 4.63 & 1.58 \\
\hline Shaft upto 10m & 344.3 & 344.36 & 17.12 & 26.486 & 28.99 & 5.11 \\
\hline
\end{tabular}

Table4. Comparison of Distribution of Base Shear in Zone - Iii

\begin{tabular}{|c|c|c|c|c|c|c|}
\hline \multirow[t]{2}{*}{ Element } & \multicolumn{2}{|c|}{ Force per unit height $(\mathbf{k N})$} & \multirow{2}{*}{$\begin{array}{l}\text { Height of } \\
\text { element }\end{array}$} & \multicolumn{2}{|c|}{ Total horizontal force } & \multirow{2}{*}{$\begin{array}{c}\text { Centre of } \\
\text { gravity }\end{array}$} \\
\hline & Tank full & Tank empy & & Tank full & Tank empty & \\
\hline Cylindrical portion & 1180.8 & 337.83 & 3.83 & 32.15 & 10.18 & 1.72 \\
\hline Conical dome & 189.452 & 189.452 & 4.83 & 6.46 & 7.12 & 0.66 \\
\hline Shaft above 10m & 132.47 & 132.47 & 7.12 & 6.64 & 7.41 & 1.58 \\
\hline Shaft upto 10m & 344.3 & 344.36 & 17.12 & 41.94 & 46.3 & 5.11 \\
\hline
\end{tabular}

Table5. Comparison of Distribution of Base Shear in Zone -iv

\begin{tabular}{|c|c|c|c|c|c|c|}
\hline \multirow[t]{2}{*}{ Element } & \multicolumn{2}{|c|}{ Force per unit height $(\mathrm{kN})$} & \multirow{2}{*}{$\begin{array}{l}\text { Height of } \\
\text { element }\end{array}$} & \multicolumn{2}{|c|}{ Total horizontal force } & \multirow{2}{*}{$\begin{array}{c}\text { Centre of } \\
\text { gravity }\end{array}$} \\
\hline & Tank full & Tank empy & & Tank full & Tank empty & \\
\hline Cylindrical portion & 1180.8 & 337.83 & 3.83 & 47.68 & 15.50 & 1.72 \\
\hline Conical dome & 189.452 & 189.452 & 4.83 & 9.58 & 10.84 & 0.66 \\
\hline Shaft above 10m & 132.47 & 132.47 & 7.12 & 9.84 & 11.26 & 1.58 \\
\hline Shaft upto 10m & 344.3 & 344.36 & 17.12 & 62.19 & 70.47 & 5.11 \\
\hline
\end{tabular}

Table6. Comparison of Distribution of Base Shear in Zone - V

\begin{tabular}{|c|c|c|c|c|c|c|}
\hline \multirow{2}{*}{ Element } & \multicolumn{2}{|c|}{ Force per unit height $\mathbf{( k N )}$} & \multirow{2}{*}{$\begin{array}{c}\text { Height of } \\
\text { element }\end{array}$} & \multicolumn{2}{|c|}{ Total horizontal force } & Centre of \\
\cline { 2 - 3 } & Tank full & Tank empy & Tank full & Tank empty & gravity \\
\hline Cylindrical portion & 1180.8 & 337.83 & 3.83 & 71.95 & 22.9 & 1.72 \\
\hline Conical dome & 189.452 & 189.452 & 4.83 & 14.46 & 16.03 & 0.66 \\
\hline Shaft above 10m & 132.47 & 132.47 & 7.12 & 14.85 & 16.67 & 1.58 \\
\hline Shaft upto 10m & 344.3 & 344.36 & 17.12 & 93.84 & 104.21 & 5.11 \\
\hline
\end{tabular}


Comparative Study of Analysis of Elevated Water Tank Due To Earth Quake from Different Zones of Earth Quake

Table7. Summary of forces and Total Loads on the Tank

\begin{tabular}{|c|c|c|c|c|c|c|c|c|}
\hline \multirow{2}{*}{ Element } & \multicolumn{2}{|c|}{$\begin{array}{c}\text { Force per unit } \\
\text { height }\end{array}$} & \multicolumn{2}{|c|}{ Height of element } & \multicolumn{2}{|c|}{ Total horizontal force } & \multicolumn{2}{c|}{$\begin{array}{c}\text { C.G of force } \\
\text { from the ground }\end{array}$} \\
\cline { 2 - 9 } & $\begin{array}{c}\text { Wind } \\
\text { force }\end{array}$ & $\begin{array}{c}\text { Seismic } \\
\text { force }\end{array}$ & $\begin{array}{c}\text { Wind } \\
\text { force }\end{array}$ & $\begin{array}{c}\text { Seismic } \\
\text { force }\end{array}$ & $\begin{array}{c}\text { Wind } \\
\text { force }\end{array}$ & $\begin{array}{c}\text { Seismic } \\
\text { force }\end{array}$ & $\begin{array}{c}\text { Wind } \\
\text { force }\end{array}$ & $\begin{array}{c}\text { Seismi } \\
\text { c force }\end{array}$ \\
\hline $\begin{array}{c}\text { Cylindrical } \\
\text { portion }\end{array}$ & 15.78 & 337.38 & 2.6 & 3.83 & 41.028 & 10.18 & 14.6 & 1.72 \\
\hline $\begin{array}{c}\text { Conical } \\
\text { dome }\end{array}$ & 13.69 & 189.45 & 1.3 & 4.83 & 17.79 & 7.12 & 13.04 & 0.60 \\
\hline $\begin{array}{c}\text { Shaft above } \\
\mathbf{1 0 m}\end{array}$ & 1.896 & 132.47 & 2.0 & 7.12 & 3.792 & 7.41 & 11 & 1.58 \\
\hline $\begin{array}{c}\text { Shaft upto } \\
\mathbf{1 0 m}\end{array}$ & 1.8 & 344.36 & 10.0 & 17.12 & 18.0 & 46.3 & 5 & 5.11 \\
\hline
\end{tabular}

9. Conclusions

- The forces acting on the elevated water tank due to seismic forces are calculated for all the zones.

- The Base shear, Base moment and Hydrodynamic pressures are increases from Zone II to Zone IV.

- Base shear is increases 3 to $6 \%$ and Hydrodynamic pressure is increases from 17 to $28 \%$ from Zone II to Zone III.

- Base shear is increases 6 to $9 \%$ and Hydrodynamic pressure is increases from 28 to $43 \%$ from Zone III to Zone IV.

- Base shear is increases 9 to $10 \%$ and Hydrodynamic pressure is increases from 43 to $61.7 \%$ from Zone IV to Zone V.

- Base shear and Base moment values obtained in the tank full condition are greater than the values obtained in the tank empty condition, so the design will be governed by tank full condition.

- By comparing the seismic forces and wind forces the weight per unit height is more due to seismic for than wind forces.

- Horizontal forces higher at bottom level due to seismic effect and it is decreases from bottom to top.

- Horizontal forces higher at top level due to wind effect and it is decreases from bottom and the elevated water tank should be designed by considering the both the conditions.

\section{REFERENCES}

[1] BIS Draft code on IS: 1893-part 2, "Criteria for Earthquake Resistant Design of Structure, Liquid Retaining Tanks Elevated and Ground Supported (fifth revision of IS: 1893)", Workshop on Revision of IS Codes on LRS.

[2] Beheshtian.N, Omidinasab. F and Shakib.H, "Seismic Response Evaluation of the RC Elevated Water Tank with Fluid-Structure Interaction", KSCE Journal of Civil Engineering (2012).

[3] IS: 1893(2002) "Criteria for Earthquake Resistant Design of Structures"

[4] IITK-GSDMA guidelines for seismic design of liquid storage tanks.

[5] Dutta, S.C., Jain, S.K. and Murty, C.V.R., (2000). "Assessing the Seismic torsional Vulnerability of Elevated Tanks with RC Frame Type staging", Soil Dynamics and Earthquake Engineering.

[6] Ajagbe, W.O.1, Adedokun2, S.I. and Oyesile W.B.1 "Comparative Study on the Design of Elevated Rectangular and Circular Concrete Water Tanks", International Journal of Engineering Research and Development ISSN: 2278 


\section{AUTHORS' BIOGRAPHY}

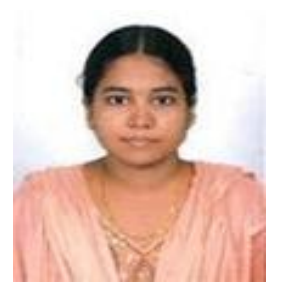

P.L.N. Saroja, Student of Final Year M.Tech Structural Engineering Usha Rama College of Engineering and Technology, Andhra Pradesh.

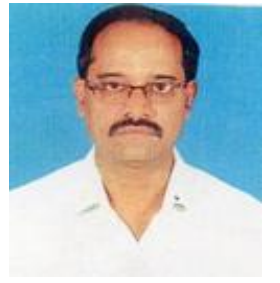

Vanka. Srinivasa Rao, B.E,M.Tech (NIT-W), (Ph.D.) Associate Professor, Civil Engineering Department Usha Rama College of Engineering and Technology, Andhra Pradesh. 